in the West, a few words about these trends would have been desirable especially since even Russians of the third millennium continue to turn to "non-psychiatric healing practices" (296).

The collection of essays is both an excellent introduction to madness and an opportunity to probe this fascinating terrain in depth. It avoids focusing on the common story of Soviet psychiatry, a story that is well known, and therefore gives the reader the opportunity to explore alternatives. Similarly, it does not just condemn Russia for backwardness - while admitting that the Russian psychiatric profession had a late start, it indicates the important advances and attitudes developed in the Russian Empire and the Soviet Union. More importantly, it provides a complex web of viewpoints about the most complex terrain, the human mind.

Nigel Raab

Loyola Marymount University

\title{
Winfried Siemerling, The Black Atlantic Reconsidered: Black Canadian Writ- ing, Cultural History, and the Presence of the Past (Montreal \& Kingston: McGill-Queen’s University Press, 2015). 560pp. Paperback \$34.95.
}

Winfried Siemerling's The Black Atlantic Reconsidered is fundamentally interdisciplinary in nature, and will undoubtedly be used heavily for teaching in fields such as literature and critical race theory. Rather than providing an account of the book's uses in various fields, my focus in this review is particularly on how the book can be drawn upon by historians in a variety of geographic fields. Siemerling's work, and in particular his theories on time and memory, is of exceptional value to historians, beyond just those studying black Canada.

Siemerling's book situates black Canadian writing and history as a crucial nexus in the black Atlantic world. He also shows how this writing, from the eighteenth century onward, is simultaneously local, diasporic, transatlantic, and hemispheric in nature; while many prominent black Canadian writers from the 1960s, for instance, were born in the Caribbean, their writing is nonetheless as locally implicated as it is transnational. This conception of geography and space builds on Stuart Hall's theories on belonging and identity in diaspora, and makes a unique and powerful contribution to these ideas.

In his insightful and complex introduction, Siemerling reflects critically on the idea that black Canadian writing has been understood to embody melancholia. He argues that instead the hauntings that appear in black Canadian writing, and the wider importance of the past in contemporary black Canadian writing, speak to optimism in the form of highlighting possibilities for black futures. He draws heavily on the work of Eduoard Glissant (14) as well as Jacques Derrida (23-24) and Stuart Hall (13-15) to engage in this analysis, and these themes remain consistently prominent throughout the book. 
Siemerling's first section discusses the earliest textual narratives of blacks in Canada, including slave narratives and the Book of Negroes. He then moves on to a detailed discussion of black Canadian writing in the nineteenth century. In this section he highlights the role of gender in black writing and activism, giving a particularly detailed and interesting account of the life and work of Mary Ann Shadd (97-119). Siemerling also shows how writers in Canada engaged in debates on black education, before the more publicized debates in the United States later in the 19th century (93).

The lengthiest section of the book discusses contemporary writing, focusing on the 1960 s onward. The writing highlighted in this section is, in terms of theme and narrative, deeply rooted in slavery as well as Canada's nineteenth century. Thus, while the book follows a chronological scheme, the sections are interwoven in a way that reflects the nature of memory and time herein highlighted by the author as a major element in black Canadian writing and history.

Among the most powerful and exciting parts of this book are Siemerling's many reflections on temporalities. In particular, he posits that time has and can be understood as accumulative, rather than linear, which creates a dynamic relationship between pasts, presents, and futures and makes sense of the power the histories of slavery, trauma, and early black settlement have over present black lives, and wider meanings of Canada today. By accepting and giving credence to these understandings of time, Siemerling gives more than passing acknowledgement of non-western understandings of time and reality. If we acknowledge that it is possible for time to be accumulative rather than linear, it is easier to understand why the history of slavery still has such power to inform the present world.

Similarly, Siemerling also allows for much nuance in definitions of historical truth and memory, and how knowledge can be gained. For example, he argues that creation can be as valuable as re-creation in the telling and witnessing of stories of enslavement and liberation in black Canadian history. This is particularly valuable for historians who attempt to write histories of subjects for whom there remain only fragments of written documentation, and what documentation does exist is always mediated through other, often white, writers, in a variety of geographic fields. In telling stories of these people who are silenced by the historical records, Siemerling shows the value of constructing narratives that speak deeply to the truths of traumas, liberation, activism, and power relations in history.

In his section on the ways in which contemporary black writing engages with the past, Siemerling posits that, "While historical records offer some information, the resources of literary writing allow imagining vital realities beyond the traces left by history" (186). His use of the word realities here is provocative and challenging. Not only does literature offer an opportunity for the dissemination of art and information, it can allow for the discovery of knowledges and realities hidden by a silencing historical record. By accepting the truths therein uncovered as realities rather than mythologies, possibilities are opened for black futures. 
Seimerling also draws our attention to the many ways in which it is necessary to witness the past. A common theme in many of the novels he discusses is characters witnessing the narratives of others; In Lorris Elliott's Other Voices, for instance, Mary Ann Shadd communicates with the ghost of Angelique, playing witness to her story (156-157); in Lawrence Hill's Any Known Blood, the protagonist becomes a witness as he researches his family history (158). Seimerling argues that the readers of these books are likewise called upon to act as witnesses to the stories unfolding within. Witnesses becomes an active rather than a passive phenomenon, wherein the participants have a real and enabling power to bring crucial truths from the past into the present.

Overall, Siemerling's book should be recommended to not just those with an interest in black Canadian writing, but anyone who studies the history of Canada, or the histories of Africans and their descendants in any part of the world. It is also a highly useful tool for educators seeking to provide historical narratives that more fairly represent these crucial aspects of the histories of Canada and the black Atlantic at large.

Maryann Buri

York University

\section{Wendy Matsumura, The Limits of Okinawa: Japanese Capitalism, Living Labor, and Theorizations of Community (Durham: Duke University Press, 2015). 288pp. Hardback \$94.95.}

This is by far the best history available in English of Okinawa between 1879, when it was forcibly annexed by Japan, and the depression years of the 1930s. Appropriately focusing on economics, Matsumura persuasively applies current interpretations of Marxist theory to show the political, social and cultural effects of corporate and government efforts to make of Okinawans what Marx called "dead labor" for the sugar and textile industries, and describes how workers and farmers resisted them. The author defines "struggles between living labor-that part of labor associated with the needs and desires of workers and producers - and dead labor-the uncreative and unproductive part of the organic composition of capital" (118). Mainland corporations, often with the support of the national and prefectural governments, sought to force Okinawan growers to supply maximum quantities of sugar, Okinawa's largest cash crop, in an easily processed form for mass-production in factories at inferior wages and working conditions. For their part, the growers fought to retain control over what they produced and the land they farmed, as well as the power to negotiate wages and working conditions.

Matsumura argues against histories of Okinawa based on narratives of dependency and victimization. Instead of assuming, as many authors do, that the government in Tokyo was responsible for imposing harsh policies on Okinawa, she 